Marianne Van Remoortel, "A Poem Wrongly Ascribed to Johnson and to Coleridge," Notes and Queries 57.2 (2010): 211-213.

\title{
A POEM WRONGLY ASCRIBED TO JOHNSON AND TO COLERIDGE
}

In his 2001 edition of The Collected Works of Samuel Taylor Coleridge, J. C .C. Mays includes a poem entitled 'To Delia' as possibly composed by Coleridge in October or November 1799.

O Thou whose love-inspiring Air

Delights, yet gives a thousand Woes-

My Day declines in dark Despair,

And Night hath lost her sweet Repose.

Yet who alas! like me was blest,

To others e'er thy Charms were known,

When Fancy told my raptur'd Breast

That Delia smil'd on me alone?

Nymph of my Soul, forgive my Sighs:

Forgive the jealous Fires I feel;

Nor blame the trembling Wretch who dies

When Others to thy Beauties kneel-

Lo! theirs is ev'ry pleasing Art,

With Fortune's Gifts unknown to Me: 
I only boast a simple Heart

In love with INNOCENCE \& THEE. ${ }^{1}$

The poem is 'something of a mystery', Mays comments. Addressed 'To $M^{r}$ Humphry - Ifrom the Author-', 'it exists in a single ms thought to be in C's hand,' yet neither the type of paper nor the formulation of the address supports this assumption. ${ }^{2}$ The manuscript is kept at the Houghton Library at Harvard University, in a collection of 'Miscellaneous compositions' by Samuel Taylor Coleridge (MS Eng 947.8). Research into the text of the poem, however, reveals that it was wrongly ascribed not once, but twice-first to Samuel Johnson, then to Coleridge-and was actually the work of the eighteenth-century poet and satirist John Wolcot (1738-1819).

The first printed references to 'To Delia' appeared in the early twentieth century. Described as an autograph poem by Johnson and accompanied by an engraved portrait of Johnson by James Heath, after John Opie, the manuscript was put up for auction three times in less than two decades at Anderson Auction Company, New York. It was part of the vast rare book and manuscript collections of, in consecutive order, theatrical manager Augustin Daly (1838-1899), building contractor John D. Crimmins (1844-1917) and lawyer Winston H. Hagen (1859-1918). ${ }^{3}$ Referring to

\footnotetext{
${ }^{1}$ The Collected Works of Samuel Taylor Coleridge. Poetical Works I. Poems (Reading Text), ed. J C. C. Mays (Princeton, 2001), II, 603.

2 Poetical Works I. Poems (Reading Text), 602.

${ }^{3}$ Anderson Auction Company, The Important Collection of Autograph Letters and Documents Formed by John D. Crimmins (New York, 1907), 70; Catalogue of the Library of the Late Winston H. Hagen (New York, 1918), 131. The Daly catalogue does not mention the manuscript separately, but it does list a copy of Croker's Johnsoniana, 'enlarged by the addition of original manuscripts of Dr. Johnson' (American Art Galleries, Catalogue of the Valuable Literary and Art Property Gathered by the Late Augustin Daly (New York, 1900), 191.). The Crimmins catalogue, in addition, describes 'To Delia' as 'from the collection of the late Augustin Daly'. At the Crimmins sale on 8 April 1907, the manuscript was bought for $\$ 50$ by the
} 
the Hagen sale on 14 May 1918, the two editions of The Poems of Samuel Johnson $(1941,1974)$ and the prestigious Yale Edition of the Works of Samuel Johnson (1964) report the existence of 'To Delia' in a section of 'Lost or Unidentified Poems'. Having lost track of the manuscript after it was sold to an unknown buyer by the Brick Row Book Shop in New York in the 1920s or 30s, both editions only give the first quatrain as printed in the auction catalogue. ${ }^{4} \mathrm{~J}$. D. Fleeman's handlist of Johnson manuscripts (1967) and the Index of English Literary Manuscripts (1989), too, record the manuscript as an unlocated Johnson autograph. ${ }^{5}$ All sources identify ' $M{ }^{r}$ Humphry' as Ozias Humphry (1742-1810), a miniature painter and friend of Johnson's.

When the manuscript resurfaced in the 1970s, it was no longer attributed to Johnson but to Coleridge. On 24 July 1974, it was sold to the Houghton Library as an authenticated Coleridge autograph by Goodspeed's Book Shop in Boston. Library records make no mention of any previous owners. ${ }^{6}$ The library catalogue also names Humphry as addressee, although there is no evidence to show that Coleridge and Ozias Humprhy were acquainted. Mays, on the other hand, suggests that Coleridge may have addressed the poem to Bristol chemist Humphry Davy, whom he had met in October 1799 through his publisher Cottle.

leading New York book dealer George D. Smith (1870-1920), who most likely sold it to Winston H. Hagen at some point between 1907 and 1918, the year of Hagen's death. ('\$11,000 Raised at Crimmins Sale', New York Times (9 April 1907), n.p .)

${ }^{4}$ The manuscript was sold by the Brick Row before the shop moved to Texas in 1953. Records of the shop's early years, now kept at the Grolier Club in New York, are unfortunately incomplete. I am grateful to John Crichton of the Brick Row Book Shop for his help.

${ }^{5}$ Samuel Johnson, The Poems of Samuel Johnson, ed. David Nichol Smith and Edward L. McAdam (Oxford, 1941), xxiv and (Oxford, 1974), 472. Samuel Johnson, The Yale Edition of the Works of Samuel Johnson, ed. Edward L. McAdam and George Milne (New Haven, 1964), IV, 395. J. D. Fleeman, $\underline{A}$ Preliminary Handlist of Documents and Manuscripts of Samuel Johnson (Oxford, 1967), 40. Margaret M. Smith, Index of English Literary Manuscripts (London, 1989), III, 138.

${ }^{6}$ I am grateful to Jennie Rathbun of the Houghton Library for this information. The Houghton Library has a collection of Goodspeed's papers, which may contain references to 'To Delia', but these papers have not yet been catalogued. 
Neither the first attribution to Johnson nor the more recent one to Coleridge is correct. While handwriting is not an infallible guide to authorship, the manuscript of 'To Delia' exhibits more similarities with the handwriting of John Wolcot than with that of Johnson or Coleridge. More convincingly, the poem was first published under a different title, 'To Cynthia', by Wolcot (as 'Peter Pindar') in Lyric Odes for the Year 1785 (1785), fourteen years before Mays's date for the Houghton manuscript. ${ }^{7}$ The only differences with the Houghton text are the dedication to Cynthia, the use of the adjective 'pleasing' rather than 'winning' in the first line of the final stanza, and a number of typographical variations. The publishing history of the poem, which Johnson and Coleridge scholars believed to exist in a single manuscript, is impressive. Not only did it appear in each of the seven editions of Lyric Odes and in the numerous English and American editions of The Works of Peter Pindar, from the late eighteenth to the mid-nineteenth century it was reprinted more than twenty times in various periodicals, poetry anthologies and song books. ${ }^{8}$

Ozias Humphry remains the most likely addressee of the manuscript. Wolcot had known Humphry at least eight years before the first edition of Lyric Odes and exchanged letters with him. ${ }^{9}$ Two autograph manuscripts in the British Library and the Royal Academy collections-the first addressed to 'To Mr Humphrys on seeing his

\footnotetext{
${ }^{7}$ Peter Pindar, Lyric Odes for the Year 1785 (London, 1785).

${ }^{8}$ See, for example, Peter Pindar, "Song. To Cynthia", The Universal Songster or Harmony and Innocence: An Elegant and Polite Selection of Modern and Approved Songs (London, [1785]), 219; John Wolcott, "[O Thou! whose love-inspiring air]", The Lyre of Love, ed. P. L. Courtier (London, 1806), II, 80; Peter Pindar, "To Cynthia", The Works of Peter Pindar (Philadelphia, 1835), 175-6.

${ }^{9}$ Thomas Girtin, Doctor With Two Aunts. A Biography of Peter Pindar (London, 1959), 65.
} 
pictures', the second 'To Mr. Humphrey on his Return from Italy'-show him dedicating poems to Ozias Humphry in the same way as the author of 'To Delia' ${ }^{10}$

'The uncertainty [with regard to the authorship of the manuscript] could be resolved only with the emergence of further evidence', Mays concludes in his discussion of 'To Delia'. ${ }^{11}$ The new evidence that has emerged now not only identifies John Wolcot as the author of 'To Delia', but also reveals how the manuscript has led two very different lives over the past century, travelling first as a Johnson autograph and later as a Coleridge autograph between private manuscript collections, auction houses and bookshops before moving to its current location in the Coleridge collection of Harvard's Houghton Library.

MARIANNE VAN REMOORTEL

Ghent University

\footnotetext{
${ }^{10}$ Verses, 'To Mr Humphrys on seeing his pictures' (British Library MS add. 47790 ff. 134-5). 'To Mr. Humphrey on his Return from Italy' (9 Aug. 1777; Royal Academy collections HU/2/57).

${ }^{11}$ The Collected Works of Samuel Taylor Coleridge. Poetical Works II. Poems (Variorum Text), ed. J. C. C. Mays (Princeton, 2001), 791.
} 